\title{
Potensi Genistein pada Sistem Reproduksi Mencit sebagai Penyusunan Bahan Ajar Fisiologi Reproduksi
}

\author{
Cicilia Novi Primiani \\ Pendidikan Biologi-Universitas Negeri Malang
}

INFO ARTIKEL

Riwayat Artikel:

Diterima: 17 Januari 2018

Disetujui: 9 Mei 2018

\section{Kata kunci:}

Genisetin

Sistem reproduksi

Kuantitatif eksperimental

Rancangan acak kelompok

\author{
Alamat Korespondensi: \\ Cicilia Novi Primiani \\ Pendidikan Biologi \\ Pascasarjana Universitas Negeri Malang \\ Jalan Semarang 5, Malang 65145 \\ E-mail: primianibiomipa@yahoo.co.id
}

\begin{abstract}
This study aims to genistein's performance examination on male mice (Mus musculus) reproductive system. This research is expected to be used as preparation of instructional media on physiology subject in college. This study employs quantitative experimental and the design of this study follows random sampling technique. The independent variable of this study is genistein dosage as big as $0 \mathrm{mg} / \mathrm{g}, 0.0035 \mathrm{mg} / \mathrm{g}, 0.0042 \mathrm{mg} / \mathrm{g}$, and 0.0049 $\mathrm{mg} / \mathrm{g}$. The result of this study shows that there is a genistein effect in mice (Mus musculus) reproduction. Genistein given with 0.0035 dosage $\mathrm{mg} / \mathrm{g}$; $0.0042 \mathrm{mg} / \mathrm{g}$; and $0.0049 \mathrm{mg} / \mathrm{g}$ affect the amount of germinal cells, morphology and spermatozoa viability.

Abstrak: Penelitian ini bertujuan untuk menguji pengaruh genistein terhadap sistem reproduksi mencit jantan (Mus musculus). Memanfaatkan hasil penelitian pengaruh genistein terhadap sistem reproduksi mencit jantan (Mus musculus) sebagai bahan untuk menyusun bahan ajar mata kuliah fisiologi. Penelitian ini menggunakan pendekatan kuantitatif eksperimental, yang rancangannya mengikuti Rancangan Acak Kelompok. Variabel bebas adalah dosis genistein $0 \mathrm{mg} / \mathrm{g}, 0,0035 \mathrm{mg} / \mathrm{g}, 0,0042 \mathrm{mg} / \mathrm{g}$, dan $0,0049 \mathrm{mg} / \mathrm{g}$. Hasil penelitian menunjukkan bahwa ada pengaruh genistein pada sistem reproduksi mencit (Mus musculus). Genistein yang diberikan dengan dosis $0,0035 \mathrm{mg} / \mathrm{g} ; 0,0042 \mathrm{mg} / \mathrm{g}$; dan $0,0049 \mathrm{mg} / \mathrm{g}$ berpengaruh terhadap jumlah sel germinal dalam tubulus seminiferus testis, morfologi dan viabilitas spermatozoa.
\end{abstract}

Keikutsertaan pria dalam program Keluarga Berencana (KB) masih relatif rendah apabila dibandingkan dengan wanita. Data Badan Koordinasi Keluarga Berencana Nasional pada tahun 2009 menunjukkan keikutsertaan pria dalam KB hanya 2,8\%. Keterbatasan dalam pilihan metode kontrasepsi merupakan salah satu alasan utama rendahnya peran serta pria dalam KB. Sampai saat ini metode kontrasepsi pria masih terbatas penggunaan kondom dan vasektomi. Permasalahan tersebut merupakan landasan bahwa teknologi kontrasepsi pria perlu lebih dikembangkan.

Pengembangan metode kontrasepsi pria terus menerus dilakukan antara lain dengan pemberian preparat hormonal dan imunokontrasepsi tetapi sampai saat ini belum dapat diterapkan pada masyarakat karena aplikasinya tidak mudah yaitu dengan cara diinjeksikan. Selain itu usaha untuk mendapatkan sarana kontrasepsi pria telah banyak dilakukan pula dengan memanfaatkan bahan alami yang berasal dari tanaman (Depkes, 2006) tetapi hasilnya belum memuaskan, sehingga penerapannya sebagai kontrasepsi pria masih diragukan.

Berdasarkan hasil penelitian yang telah dilakukan oleh (Cardoso, Mondadori, Bianchini, \& Báo, 2007; Delmonte \& Rader, 2006) ditemukan bahwa senyawa isoflavon yang terdapat pada tanaman famili Leguminoceae mengandung derivat senyawa daidzein, genistein dan glycitein, Menurut hasil penelitian (Barlow, Johnson, \& Scofield, 2007) kandungan isoflavon pada biji kedelai berkisar 9,4 mg/g yang diduga 
memiliki kemampuan antifertilitas. Sejumlah penelitian terkait dengan hal ini antara lain, penelitian yang telah dilakukan oleh (Setchell, Zimmer-Nechemias, Cai, \& Heubi, 1998) menyatakan bahwa isoflavon menginduksi abnormalitas sistem reproduksi jantan. (Chavarro, Toth, Sadio, \& Hauser, 2008) dalam hasil penelitiannya menyatakan bahwa isoflavon yang diberikan secara per oral pada manusia dapat menurunkan konsentrasi sperma. Penelitian yang telah dilakukan oleh (Kuntana, 2009) menjelaskan bahwa pemberian ekstrak kedelai dapat menurunkan kualitas sperma pada kelinci (Oryctolagus cuniculus).

Genistein sebagai salah satu senyawa derivat isoflavon mempuyai struktur kimia mirip dengan 176estradiol yang bersifat seperti hormon steroid estrogen, yang diduga sebagai senyawa antifertilitas. Sampai saat ini penelitian-penelitian pengaruh genistein terhadap sistem reproduksi khususnya sistem reproduksi jantan masih terus dilakukan, Sebenarnya genistein sebagai senyawa sintetis sudah banyak dipasarkan di masyarakat, tetapi manfaat senyawa tersebut sebagai anti fertilitas belum banyak dikenal. Sejumlah penelitian tentang genistein sebagai senyawa antifertilitas yang terkait dengan sistem reproduksi jantan telah dilakukan oleh (Lee et al., 2004b) menjelaskan bahwa pemberian genistein pada tikus jantan dewasa dengan dosis $2,5 \mathrm{mg} / \mathrm{kg}$ menyebabkan terjadinya hiperplasia sel-sel epitelium kelenjar prostat. (Lee et al., 2004a) menjelaskan bahwa pemberian genistein pada tikus jantan masa pubertas sedikit menurunkan jumlah sperma dalam testis dan epididimis, serta menyebabkan hiperplasia sel Leydig dan meningkatkan fibroblas interstisial dalam epididimis. Penelitian yang telah dilakukan oleh (Opalka, Kaminska, Ciereszko, \& Dusza, 2004) menjelaskan bahwa pemberian genistein pada ayam dapat menurunkan sekresi hormon testosteron. Pemberian genistein mampu menghambat aktivitas protein tirosin kinase pada saat kapasitasi dan motilitas spermatozoa (Bajpai, Asin, \& Doncel, 2003). (Shibayama et al., 2001) menjelaskan bahwa genistein yang diberikan pada tikus dengan dosis $10 \mu \mathrm{g}, 100 \mu \mathrm{g}$, dan $1000 \mu \mathrm{g}$ mampu menurunkan tingkat reseptor estrogen di dalam sel Leydig, menurunkan berat testis, dan menurunkan motilitas spermatozoa.

(Kuiper et al., 1998) menjelaskan bahwa genistein mempunyai afinitas terhadap reseptor estrogen dalam testis dan epididimis, sehingga mempunyai mekanisme kerja seperti hormon estrogen. (Handelsman, Wishart, \& Conway, 2000) menjelaskan bahwa keberadaan estradiol dapat meningkatkan hambatan pada proses spermatogenesis. Aktivitas genistein yang menyerupai hormon estrogen mampu menurunkan sekresi Luteinizing Hormone (LH) dan Follicle Stimulating Hormone (FSH) sehingga dapat menghambat spermatogensis. Hal tersbut juga akan mempengaruhi proses maturasi spermatozoa dalam epididimis, sehingga dapat menurunkan motilitas dan viabilitas spermatozoa. Berdasarkan hasil penelitian yang telah dilakukan oleh (Akiyama et al., 1987; Alexandrakis et al., 2003) bahwa pemberian genistein secara in vitro, mampu menghambat aktivitas protein tirosin kinase pada saat proliferasi sel dalam tubulus testis.

Berdasarkan kenyataan bahwa genistein sebagai salah satu sanyawa antifertilitas yang mampu bekerja pada sistem reproduksi jantan, maka dipandang perlu untuk meneliti potensi genistein terhadap sistem reproduksi jantan. Oleh sebab itu, tujuan dari penelitian ini adalah untuk menguji potensi genistein pada sistem reproduksi hewan coba mencit jantan (Mus musculus).

Hasil penelitian ini dapat digunakan dalam pengembangan bahan ajar untuk mahasiswa S1 di Perguruan Tinggi yang berupa modul pada mata kuliah Fisiologi pokok bahasan sistem reproduksi. Penyusunan modul yang berupa hasil penelitian ini merupakan salah satu pengembangan bahan ajar yang bersifat kontekstual. Hasil penelitian yang telah dilakukan oleh (Primiani \& Susianingsih, 2010) menyatakan bahwa materi pembelajaran yang dikemas secara kontekstual dapat meningkatkan prestasi belajar.

Kompetensi dasar mata kuliah fisiologi hewan pada pokok bahasan sistem reproduksi di IKIP PGRI Madiun adalah memahami konsep dan prinsip fisiologi reproduksi. Mahasiswa sering mengalami kesulitan dalam pemahaman konsep, karena pengembangan materi belum secara kontekstual. Tidak banyak bahan ajar yang berupa modul sebagai salah satu sumber belajar bagi mahasiswa yang disusun secara kontekstual berdasarkan hasil-hasil penelitian.

Pengembangan produk bahan ajar ini dipilih salah satu model yaitu rancangan Dick dan Carey dengan alasan: 1) memiliki format pembelajaran terprogram, sehingga dapat digunakan untuk keperluan belajar perorangan (individualized instruction); 2) dapat digunakan dalam mengembangkan bahan pembelajaran; 3) dapat digunakan untuk pembelajaran pada ranah belajar keterampilan intelektual yang didalamnya berisi konsep, prinsip, kaidah dan pemecahan masalah; dan 4) dapat digunakan dalam belajar kognitif, 5) model Dick dan Carey merupakan rancangan pengembangan yang lengkap.

Melalui pengembangan bahan ajar yang berupa modul berdasarkan hasil penelitian ini diharapkan dapat meningkatkan pemahaman konsep sistem reproduksi. Referensi yang diperoleh dari hasil penelitian yang 
digunakan dalam dalam penyusunan modul ini dapat membantu mahasiswa belajar secara mandiri dalam memecahkan permasalahan khususnya permasalahan-permasalahan sistem reproduksi yang dapat menggambarkan sesuatu konsep yang bersifat abstrak, sehingga mampu dipahami oleh mahasiswa.

\section{METODE}

\section{Hewan percobaan}

Hewan coba yang digunakan dalam penelitian ini adalah mencit (Mus musculus) galur Balb/c jantan, dalam kondisi sehat, berumur 9 minggu, yang berjumlah 24 ekor. Semua mencit yang digunakan mempunyai bobot badan minimal 20 gram, yang dipelihara dalam kandang mencit Jurusan Biologi FMIPA Universitas Negeri Malang.

\section{Pemeliharan mencit dan pembuatan bahan uji}

Mencit ditempatkan dalam kandang mencit, dengan diberi makan dan air secara ad libitum dan diaklimatisasi selama 14 hari sebelum perlakuan induksi. Mencit dipelihara pada suhu ruang ( $\pm 27^{\circ} \mathrm{C}$ ), kelembaban relatif antara 50-60\% dan siklus pencahayaan 12 jam. Setiap hari mencit ditimbang, sebagai dasar untuk menentukan volume larutan genistein.

Berdasarkan hasil penelitian yang telah dilakukan oleh (Lee et al., 2004a) yang mengujikan genistein pada tikus jantan dengan dosis 2,5 mg/kg. Berdasarkan konversi dosis menurut (Harmita, 2005), maka dosis genistein yang diberikan pada mencit jantan adalah $0 \mathrm{mg} / \mathrm{g}$ sebagai perlakuan kontrol sebagai perlakuan 1 (P1) dosis $0.035 \mathrm{mg} / \mathrm{g}$ sebagai perlakuan 2 (P2), dosis 0,042 mg/g sebagai perlakuan 3 (P3), dan dosis 0,049 $\mathrm{mg} / \mathrm{g}$ sebagai perlakuan 4 (P4). Setelah menentukan dosis genistein, maka perlu dilakukan uji Lethal Dosis 50 $\left(\mathrm{LD}_{50}\right)$ pada dosis tertinggi.

Selanjutnya menentukan banyaknya genistein dan banyaknya pelarut (dalam hal ini minyak jagung) dengan langkah-langkah yaitu: misalnya bobot mencit adalah 26 gram, maka genistein yang diperlukan adalah $0,0035 \mathrm{mg} / \mathrm{g} \times 26$ gram $=0,091 \mathrm{mg}$. Volume minyak jagung yang adalah $0,091 \mathrm{mg} \times 0,0025=\mathrm{V} \times$ $0,0035 \mathrm{mg} / \mathrm{g}$. Maka volume pelarut yang dibutuhkan adalah 1,24 ml. Mencampurkan genistein ke dalam minyak jagung. Larutan genistein yang di-gavage-kan pada mencit sejumlah $0,025 \mathrm{mg}$ x 26 gram = 0,65 ml. Berdasarkan asumsi bahwa pemberian volume pelarut standar pada bobot mencit standar (20 g) adalah $0,0025 \mathrm{ml}$.

\section{Pemberian larutan genistein, penentuan rerata jumlah sel-sel germinal dalam tubulus seminiferus testis, morfologi, viabilitas spermatozoa, dan kadar hormon testosteron}

Pemberian genistein dilakukan dengan cara induksi langsung ke dalam lambung dengan menggunakan alat sonde (gavage tube) sebanyak satu kali dalam sehari selama 36 hari, mengingat hal ini karena spermatogenesis mencit jantan berlangsung selama 36 hari. Setelah hari ke-36, mencit didislokasi, kemudian dibedah dan dilakukan pengambilan organ testis dan vas deferens. Pembuatan preparat histologi testis dengan metode parafin untuk menentukan rerata jumlah sel-sel germinal (spermatogonia, spermatosit primer, spermatosit sekunder, spermatid dan spermatozoa) dalam tubulus seminiferus testis. Pembuatan preparat apus sperma dengan pewarnaan eosin-nigrosin, untuk menentukan morfologi dan viabilitas spermatozoa.

Pengambilan darah langsung dari jantung. Darah mencit kemudian dipisahkan antara serum dan plasma melalui sentrifugasi pada $3000 \mathrm{rpm}$ selama 15 menit pada suhu ruang. Penentuan kadar hormon testosteron menggunakan metode Enzym Linked Immunosorbent Assay (ELISA).

\section{Analisis Data}

Data sel-sel germinal (spermatogonia, spermatosit primer, spermatosit sekunder, spermatid dan spermatozoa) dalam tubulus seminiferus testis dan kadar hormon testosteron dianalisis menggunakan One Way ANOVA $(\alpha=5 \%)$. Sebelum dilakukan uji ANOVA, data sel-sel germinal dalam tubulus seminiferus testis dan data kadar hormon testosteron terlebih dulu diuji normalitas distribusinya menggunakan One Sample Kolmogorov-Smirnov Test $(\alpha=5 \%)$, dan homogenitasnya menggunakan Levene's Homogeneity of Variance Test $(\alpha=5 \%)$, Setelah persyaratan normalitas dan homogenitas terpenuhi, data dapat dianalisis menggunakan ANOVA satu jalan, kemudian dilakukan uji post-hoc menggunakan Least Significant Difference (LSD) $(\alpha=$ $5 \%$ ). Semua uji statistik yang dipakai mulai dari uji normalitas sampi uji post-hoc menggunakan bantuan 
software SPSS versi 15 (Widiyanto, 2010). Data morfologi dan viabilitas spermatozoa dinyatakan dalam prosentase.

\section{Pengembangan Penyusunan Bahan Ajar}

\section{Model Pengembangan}

Model pengembangan modul menggunakan model Dick dan Carey, berdasarkan pada hasil penelitian merupakan bahan ajar kontekstual yang dapat mengembangkan ranah kognitif, afektif dan psikomotor bagi mahasiswa.

\section{Pengumpulan Data}

Data utama yang digunakan merupakan hasil ekperimen dari penelitian ini. Data tambahan berasal dari data hasil tinjauan pustaka yang relefan sesuai topik/judul buku.

\section{Produk Pengembangan}

Bahan ajar yang dikembangkan dari penelitian ini berupa bahan ajar bagi mahasiswa jenjang Strata 1 pada mata kuliah Fisiologi Hewan pokok bahasan sistem reproduksi.

\section{HASIL DAN PEMBAHASAN}

\section{Sel-Sel Germinal dalam Tubulus Seminiferus Testis}

Tabel 1 disajikan hasil uji analisis varians jatu jalan terhadap rerata jumlah sel-sel germinal dalam tubulus seminiferus testis diperoleh nilai $\mathrm{F}$ hitung sebesar 47,270 dan nilai signifikan 0,000. Nilai signifikan lebih kecil dari nilai a 0,05 berarti bahwa ada pengaruh signifikan pemberian genistein terhadap rerata jumlah selsel germinal dalam tubulus seminiferus testis.

Tabel 1. Uji ANOVA Perlakuan Genistein (Kontrol, Dosis 0,0035 mg/g, Dosis 0,0042 mg/g, dan Dosis 0,0049 mg/g) Terhadap Rerata Jumlah Sel-Sel Germinal

\begin{tabular}{cccccc}
\hline & Sum of Squares & df & Mean Square & F & Sig. \\
\hline Between Goups & 187690,758 & 3 & 62563,586 & 47,270 & 0,000 \\
Within Groups & 153531,033 & 116 & 1323,543 & & \\
Total & 341221,792 & 119 & & & \\
\hline
\end{tabular}

Adapun hasil uji LSD menunjukkan bahwa pada perlakuan P1, P2, P3, dan P4 merupakan dosis yang berbeda sangat nyata terhadap rerata jumlah sel-sel germinal dalam tubulus seminiferus testis. Hasil analisis statistik deskriptif pemberian genistein terhadap rerata jumlah sel-sel germinal terdapat pada Gbr 1.

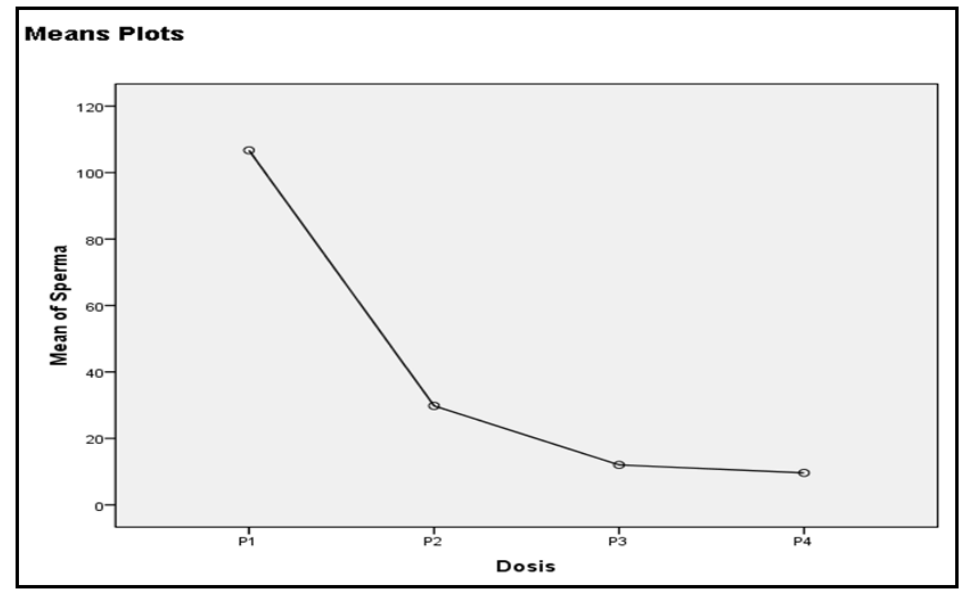

Gambar 1. Rerata Jumlah Sel-sel Germinal pada Pemberian Genistein dengan Dosis Kontrol (P1) 0,0035 mg/g (P2), 0,0042 mg/g (P3), 0,0049 mg/g (P4) 
Berdasarkan hasil pengamatan terhadap struktur jaringan tubulus seminiferus testis, maka diperoleh hasil bahwa pada perlakuan kontrol (P1) struktur jaringan tubulus seminiferus testis tidak mengalami perubahan (Gbr 2a). Penampang melintang tubulus seminiferus testis dengan pewarnaan Hematoksilin-Eosin (HE) menunjukkan bahwa tubulus seminiferus dikelilingi oleh jaringan ikat kolagen yang terdapat pada permukaan posterior testis yaitu tunika albuginea. Tubulus seminiferus dikelilingi oleh membran basal. Selsel germinal yang tidak mengalami perubahan, dan jajaran sel germinal berkembang penuh.

Hasil pengamatan terhadap histologi tubulus seminiferus testis, maka diperoleh hasil pada perlakuan pemberian genistein dosis $0,0035 \mathrm{mg} / \mathrm{g}$ (P2) tubulus seminiferus testis mengalami perubahan. Spermatogenesis tidak dapat berkembang normal, spermatogonia mempunyai karakteristik sama dengan spermatogonia perlakuan kontrol. Fase proliferasi masih dapat dijumpai, karena spermatogonium masih tampak jelas (Gbr 2b). Kondisi terhadap sel-sel germinal dalam tubulus seminiferus testis pada perlakuan pemberian genistein dosis $0,0035 \mathrm{mg} / \mathrm{g}$ (P2) sama seperti perlakuan pemberian genistein dosis 0,0042 mg/g (P3) dan dosis 0,0049 mg/g (P4), seperti terdapat pada Gbr 2c \& 2 d.

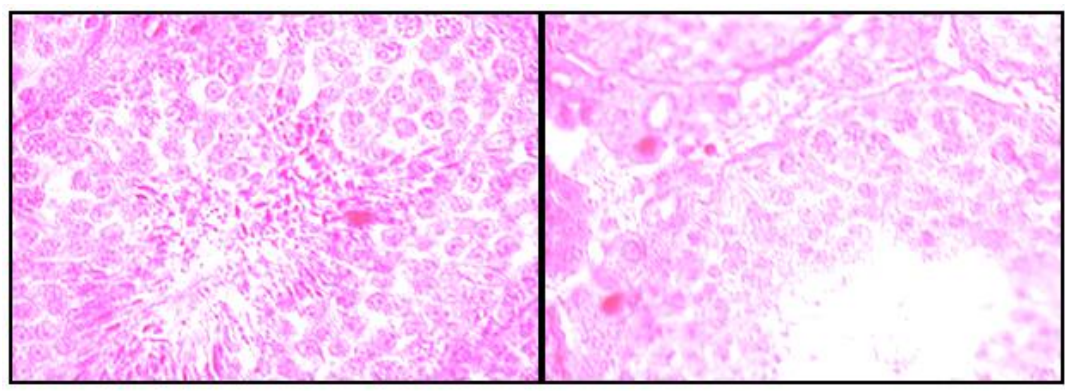

b

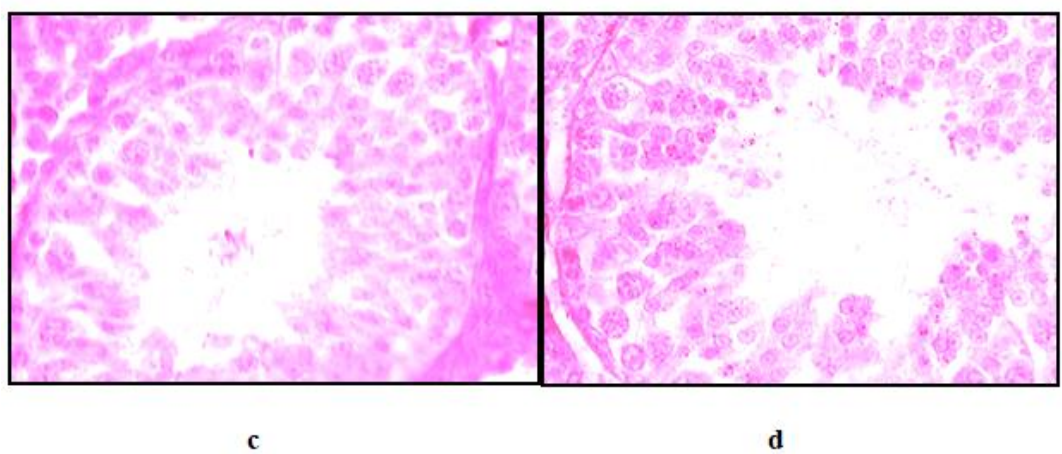

Gambar 2. Tubulus Seminiferus Testis Mencit (Mus musculus) dengan Pewarnaan HE, Perbesaran 1000X (Sumber: Primiani, 2011)
Keterangan: a. Kontrol (P1)
b. Dosis $0,0035 \mathrm{mg} / \mathrm{g}(\mathrm{P} 2)$
c. Dosis $0,0042 \mathrm{mg} / \mathrm{g}(\mathrm{P} 3)$
d. Dosis $0,0049 \mathrm{mg} / \mathrm{g}(\mathrm{P} 4)$

\section{Morfologi Spermatozoa}

Pengamatan morfologi dilakukan terhadap adanya perubahan-perubahan bentuk yang terdapat pada kepala, badan, dan ekor. Jumlah spermatozoa normal dan abnormal dihitung dari pemeriksaan terhadap 100 sel spermatozoa dan dinyatakan dalam prosentase. Perlakuan kontrol (P1) memberikan hasil morfologi spermatozoa normal sebesar 68,66\%. Pemberian genistein dosis 0,0035 mg/g (P2) morfologi spermatozoa normal sebesar 34,66\%. Dosis 0,0042 mg/g (P3) morfologi spermatozoa normal sebesar 31,66\%. Pemberian genistein dosis $0,0049 \mathrm{mg} / \mathrm{g}$ (P4), morfologi spermatozoa normal sebesar 19,83\%, hal ini menunjukkan terjadi penurunan prosentase morfologi spermatozoa normal. 


\section{Viabilitas Spermatozoa}

Viabilitas merupakan kemampuan spermatozoa untuk bertahan hidup setelah keluar dari organ reproduksi. Pengamatan dilakukan pada preparat apus sperma, selanjutnya penghitungan spermatozoa hidup dan spermatozoa mati terhadap 100 sel spermatozoa, dan dinyatakan dalam prosentase. Perlakuan kontrol (P1) spermatozoa hidup sebesar 91,83\%. Pemberian genistein dosis 0,0035 mg/g (P2) spermatozoa hidup sebesar 15,66\%. Pemberian genistein dosis $00042 \mathrm{mg} / \mathrm{g}$ (P3) spermatozoa hidup sebesar 8,83\%. Pemberian genistein dosis $0,0049 \mathrm{mg} / \mathrm{g}$ (P4), spermatozoa hidup sebesar 5,50\%. Hal ini menunjukkan terjadi penurunan prosentase spermatozoa hidup.

\section{Kadar Hormon Testosteron}

Tabel 3 disajikan hasil uji Analisis Varians Satu Jalan terhadap kadar hormon testosteron. Tabel 3. Hasil Uji ANOVA terhadap Kadar Hormon Testosteron

\begin{tabular}{cccccc}
\hline & Sum of Squares & df & Mean Square & F & Sig. \\
\hline Between Goups & 2,327 & 3 & 0,776 & 4,767 & 0,012 \\
Within Groups & 3,254 & 20 & 0,163 & & \\
Total & 5,581 & 23 & & & \\
\hline
\end{tabular}

Hasil uji analisis varians satu jalan diperoleh nilai $\mathrm{F}$ hitung sebesar 4,767 dan nilai signifikan 0,012. Nilai signifikan yang teramati lebih kecil dari nilai a 0,05 sehingga dapat disimpulkan bahwa ada pengaruh pemberian genistein terhadap kadar hormon testosteron. Berdasarkan kesimpulan hasil uji maka perlu dilakukan uji lanjut Least Significant Difference (LSD) dengan a $=5 \%$ dapat disimpulkan bahwa pada dosis $0,0049 \mathrm{mg} / \mathrm{g}(\mathrm{P} 4)$ merupakan dosis yang berbeda nyata terhadap kadar hormon testosteron.

Berdasarkan struktur kimianya yang mirip dengan estrogen, maka genistein mampu berikatan dengan reseptor estrogen sehingga memberikan aktivitas fisiologis sebagai hormon estrogen (Barlow et al., 2007; Delmonte \& Rader, 2006; Gruber, Tschugguel, Schneeberger, \& Huber, 2002; Shibayama et al., 2001). Oleh karena itu dikatakan bahwa genistein mempunyai kemampuan estrogenik, artinya bahwa genistein mampu berikatan dengan reseptor estrogen dalam sel Leydig (Kuiper et al., 1998). Menurut hasil penelitian yang telah dilakukan oleh (Abney \& Myers, 1991), kondisi tersebut menyebabkan hambatan terhadap enzim P450 17 a hidroksilase, akibatnya terjadi penghambatan pada proses steroidogenesis. Berdasarkan kondisi tersebut maka pengubahan progestron menjadi 17 a hydroksi progesteron yang memerlukan enzim P450 17a hidroksilase tidak terjadi. Hal tersebut menyebabkan penghambatan terbentuknya androstenedion, yang berakibat testosteron tidak terbentuk.

Penurunan kadar hormon testosteron berakibat terganggunya proses maturasi sperma di dalam epididimis. Menurut hasil penelitian yang dilakukan oleh (Sirivaidyapong \& Uthai, 2003) menjelaskan bahwa proses maturasi sperma membutuhkan senyawa-senyawa fruktosa, sorbitol, dan glicerylphosphorylcholine (GPC). Oleh karena terjadi penurunan kadar hormon testosteron maka berakibat sekresi senyawa-senyawa tersebut juga menurun, hal ini berakibat penurunan viabilitas sperma pada pemberian genistein dosis $0,0035 \mathrm{mg} / \mathrm{g}$ (P2), dosis 0,0042 mg/g (P3), dan dosis 0,0049 mg/g (P4).

Proses maturasi merupakan serangkaian proses yang meliputi terjadinya perubahan struktural kepala dan ekor spermatozoa yang disertai dengan peningkatan motilitas sperma yang progresif. Sesuai hasil penelitian (Visconti \& Kopf, 1998) menjelaskan bahwa spermatozoa yang berada dalam epididimis juga mengalami proses kapasitasi yang pada akhirnya mampu melakukan fertilisasi.

Turunnya kadar hormon testosteron juga mengakibatkan terjadinya gangguan pada proses spermatogenesis, yang diindikasikan dengan penurunan jumlah sel-sel germinal dalam tubulus seminiferus testis. Berdasarkan hasil analisis statistik deskriptif perlakuan pemberian genistein dosis 0,0035 mg/g (P2), $0,0042 \mathrm{mg} / \mathrm{g}$ (P3), dan dosis 0,0049 mg/g (P4) mengalami penurunan terhadap rerata jumlah sel-sel germinal dalam tubulus seminiferus testis menunjukkan bahwa rerata jumlah sel-sel germinal. Kondisi ini sesuai yang dijelaskan oleh (Akiyama et al., 1987; Alexandrakis et al., 2003) bahwa genistein mampu menghambat proliferasi sel-sel germinal dalam tubulus seminiferus testis. Menurut (Matsukawa et al., 1993) genistein mampu menahan siklus sel pada fase G2-M serta hambatan enzim tirosin kinase yang terlibat dalam meregulas terhadap proliferasi dan deferensiasi sel, siklus sel, migrasi sel, keberlangsungan hidup sel, dan modulasi pada metabolisme seluler. 


\section{SIMPULAN}

\section{Simpulan}

Hasil penelitian menunjukkan bahwa ada pengaruh pemberian genistein terhadap sistem reproduksi mencit (Mus musculus) jantan, pada sel-sel germinal dalam tubulus seminiferus testis, morfologi spermatozoa, viabilitas spermatozoa, dan kadar hormon testosteron. Berdasarkan hasil penelitian yang didapat, diperlukan sosialisai pada masyarakat mengenai genistein sebagai antifertilitas serta pengemasannya secara efektif dan efisien sehingga mudah dikonsumsi.

\section{Saran}

Menindaklanjuti kebutuhan tersebut, maka perlu pengkajian tingkat molekuler pada sel-sel germinal dalam tubulus seminiferus, Sehingga penggunaan genistein sebagai senyawa antifertilitas dapat dipertanggungjawabkan keefektifitasannya.

\section{DAFTAR RUJUKAN}

Abney, T. O., \& Myers, R. B. (1991). 176-Estradiol Inhibition of Leydig Cell Regeneration in the Ethane DimethylsulfonateTreated Mature Rat. Journal of Andrology, 12(5), 295-304.

Akiyama, T., Ishida, J., Nakagawa, S., Ogawara, H., Watanabe, S. I., Itoh, N., \& Fukami, Y. (1987). Genistein, a specific inhibitor of tyrosine-specific protein kinases. Journal of Biological Chemistry, 262(12), 5592-5595.

Alexandrakis, M. G., Kyriakou, D. S., Kempuraj, D., Huang, M., Boucher, W., Seretakis, D., \& Theoharides, T. C. (2003). The isoflavone genistein inhibits proliferation and increases histamine content in human leukemic mast cells. Allergy and Asthma Proceedings, 24(5), 373. OceanSide Publications.

Bajpai, M., Asin, S., \& Doncel, G. F. (2003). Effect of tyrosine kinase inhibitors on tyrosine phosphorylation and motility parameters in human sperm. Archives of Andrology, 49(3), 229-246.

Barlow, J., Johnson, J. A., \& Scofield, L. (2007). Fact sheet on the phytoestrogen genistein. In NIEHS/NCI Environment Research Centers,(Online), http://cerhr. niehs. nih. gov/chemicals/genistein (Vol. 8).

Cardoso, J. R., Mondadori, R. G., Bianchini, E., \& Báo, S. N. (2007). Effects of chronic treatment with soy derived isoflavones on reproductive health of male rabbits.

Chavarro, J. E., Toth, T. L., Sadio, S. M., \& Hauser, R. (2008). Soy food and isoflavone intake in relation to semen quality parameters among men from an infertility clinic. Human Reproduction, 23(11), 2584-2590.

Delmonte, P., \& Rader, J. I. (2006). Analysis of isoflavones in foods and dietary supplements. Journal of AOAC International, 89(4), 1138-1146.

Gruber, C. J., Tschugguel, W., Schneeberger, C., \& Huber, J. C. (2002). Production and actions of estrogens. New England Journal of Medicine, 346(5), 340-352.

Handelsman, D. J., Wishart, S., \& Conway, A. J. (2000). Oestradiol enhances testosterone-induced suppression of human spermatogenesis. Human Reproduction, 15(3), 672-679.

Harmita, R. M. (2005). Analisis hayati. Jakarta: Percetakan Ari Cipta, 51, 55.

Kuiper, G. G., Lemmen, J. G., Carlsson, B. O., Corton, J. C., Safe, S. H., Van Der Saag, P. T., \& Gustafsson, J. A. (1998). Interaction of estrogenic chemicals and phytoestrogens with estrogen receptor B. Endocrinology, 139(10), 4252-4263.

Kuntana, Y. P. (2009). Pengaruh Pemberian Phytoestrogen Terhadap Kualitas Spermatozoa, Spermatogenesis dan Luas Jaringan Interstitial pada Kelinci (Oryctolagus cuniculus). Jurnal Bionatura, 11(1), 47-58.

Lee, B. J., Kang, J. K., Jung, E. Y., Yun, Y. W., Baek, I. J., Yon, J. M., \& Nam, S. Y. (2004a). Effects of exposure to genistein during pubertal development on the reproductive system of male mice. Journal of Reproduction and Development, 50(4), 399-409.

Lee, B. J., Kang, J. K., Jung, E. Y., Yun, Y. W., Baek, I. J., Yon, J. M., \& Nam, S. Y. (2004b). Exposure to genistein does not adversely affect the reproductive system in adult male mice adapted to a soy-based commercial diet. Journal of Veterinary Science, 5(3), 227-234.

Matsukawa, Y., Marui, N., Sakai, T., Satomi, Y., Yoshida, M., Matsumoto, K., \& Aoike, A. (1993). Genistein arrests cell cycle progression at G2-M. Cancer Research, 53(6), 1328-1331.

Opalka, M., Kaminska, B., Ciereszko, R., \& Dusza, L. (2004). Genistein affects testosterone secretion by Leydig cells in roosters (Gallus gallus domesticus). Reproductive Biology, 4(2), 185-193.

Primiani, C. N., \& Susianingsih, M. D. (2010). Meningkatkan aktivitas dan prestasi belajar biologi melalui pendekatan kontekstual dengan media herbarium dan insektarium. Paedagogia, 13(1).

Setchell, K. D., Zimmer-Nechemias, L., Cai, J., \& Heubi, J. E. (1998). Isoflavone content of infant formulas and the metabolic fate of these phytoestrogens in early life. The American Journal of Clinical Nutrition, 68(6), 1453S-1461S. 
Shibayama, T., Fukata, H., Sakurai, K., Adachi, T., Komiyama, M., Iguchi, T., \& Mori, C. (2001). Neonatal exposure to genistein reduces expression of estrogen receptor alpha and androgen receptor in testes of adult mice. Endocrine Journal, 48(6), 655-663.

Sirivaidyapong, S., \& Uthai, S. (2003). Effect of Collection Time and Collection Temperature on Motility and Viability of Canine Epididymal Sperm. International Symposium of The World Association of Veterinary Laboratory Diagnosticians and OIE Seminar on Biotechnology, 9-13.

Visconti, P. E., \& Kopf, G. S. (1998). Regulation of protein phosphorylation during sperm capacitation. Biology of Reproduction, 59(1), 1-6.

Widiyanto, J. (2010). SPSS For Windows untuk analisis data statistik dan penelitian. Surakarta: BP-FKIP UMS. 